\title{
Pelatihan Penyusunan Naskah dan Pembuatan E-Modul bagi Guru SMAN 3 Takalar
}

\author{
Muh. Yunus*, Amran Hapsan, Khadijah, Iwan Setiawan HR \\ STKIP Pembangunan Indonesia, Jl. Inspeksi Kanal Citra Land No.10,Makassar 90222, Indonesia
}

\begin{abstract}
e-Modul merupakan merupakan salah satu jenis bahan ajar yang perlu dikembangkan sendiri oleh guru, yang berbentuk file aplikasi, bisa diakses di smartphone, komputer, laptop atau notebook dan dapat mengurangi biaya pendidikan karena tidak perlu adanya percetakan modul. Karena kebutuhan mitra di SMAN 3 Takalar dan pentingnya kemampuan membuat e-Modul maka kami mengadakan pelatihan penyusunan naskah dan pembuatan e-Modul bagi guru SMAN 3 Takalar. Metode yang digunakan dalam pelatihan ini adalah metode pembimbingan pelatihan dan pendampingan. Keberhasilan kegiatan ini dapat dilihat dari kemampuan guru menyusun naskah dan membuat e-Modul. Luaran yang terwujud dari kegiatan ini adalah: (1) peningkatan pengetahuan guru di sekolah mitra dalam mengoptimalkan pembelajaran dengan bantuan teknologi berupa e-Modul (peningkatan pemahaman dan keterampilan masyarakat), (2) peningkatan keterampilan guru di sekolah mitra dalam membuat bahan ajar e-Modul (peningkatan pemahaman dan keterampilan masyarakat), (3) terciptanya produk bahan ajar berupa e-Modul untuk beberapa mata pelajaran, (4) peningkatan kualitas produk bahan ajar dari slide persentase materi dan modul hasil cetakan yang membutuhkan biaya besar menjadi e-Modul.
\end{abstract}

Keywords: Penyusunan naskah; pembuatan e-Modul; pembelajaran online.

\section{Pendahuluan}

Perkembangan teknologi telah merambah ke berbagai bidang kehidupan, termasuk dalam bidang pendidikan. Sebagaimana disampaikan oleh intel education dalam Rusman (2013), sekolah-sekolah di abad ke-21 tidak sekedar menyiapkan siswanya untuk bekerja di tempat kerja masa kini, tetapi juga harus mengikuti perkembangan cara siswa dalam menggunakan teknologi dalam kehidupan mereka sehari-hari. Salah satu bentuk perkembangan teknologi dalam bidang pendidikan yaitu penggunaan perangkat komputer di sekolah-sekolah. Komputer menjadi suatu hal yang menarik bagi siswa, yang dapat menambah motivasi siswa dalam belajar. Komputer juga memudahkan guru menyampaikan pembelajaran (Khadijah, 2018).

Telah banyak inovasi-inovasi pembelajaran yang dilakukan guru dalam bidang teknologi, seperti pemanfaatan LCD dan presentase menggunakan aplikasi Microsoft Office PowerPoint dalam menyampaikan materi pembelajaran. Namun penggunaan aplikasi presentase tersebut hanya dapat digunakan dalam pembelajaran peserta didik di dalam kelas. Di luar kelas dan jam pelajaran, siswa sudah tidak bisa lagi mengakses materi yang disampaikan lewat presentase tersebut. Dan penggunaan aplikasi presentase hanya menampilkan materi-materi pembelajaran saja, tidak ada aktivitas peserta didik. Padahal sistem pembelajaran sudah bersifat student center dimana peserta didik diharapkan aktif dalam menemukan sendiri pengetahuan sesuai kompetensinya, dan peserta didik aktif melakukan

\footnotetext{
* Corresponding author:

E-mail address: khadijah0611@gmail.com
} 
latihan-latihan sendiri dalam pemecahan masalah yang terjadi. Karena itu perlu teknologi yang lebih baik lagi yang menunjang tujuan pembelajaran dan sistem belajar termutakhir. Salah satunya dengan pembuatan dan penggunaan eModul.

e-Modul merupakan merupakan salah satu jenis bahan ajar yang berbentuk file aplikasi, bisa diakses di smartphone, komputer, laptop atau notebook dan dapat mengurangi biaya pendidikan karena tidak perlu adanya percetakan modul. Terdapat sejumlah alasan, mengapa guru perlu untuk mengembangkan bahan ajar, yakni antara lain; ketersediaan bahan sesuai tuntutan kurikulum, karakteristik sasaran, dan tuntutan pemecahan masalah belajar. Penelitian (Muthuprasad et al., 2021) menemukan bahwa siswa lebih memilih kelas yang direkam dengan kuis di akhir setiap kelas untuk meningkatkan keefektifan pembelajaran. Penelitian (Kucirkova et al., 2020) juga menemukan bahwa konsep 'komunitas praktik' penting untuk memandu perkembangan studi masa depan. Bahan ajar membantu siswa merekam kuis-kuis pembelajaran dan menuntun siswa dalam pelaksanaan paraktik pembelajaran. Pengembangan bahan ajar harus memperhatikan tuntutan kurikulum, artinya bahan belajar yang akan kita kembangkan harus sesuai dengan kurikulum. Pada kurikukulum tingkat satuan pendidikan, standar kompetensi lulusan telah ditetapkan oleh pemerintah, namun bagaimana untuk mencapainya dan apa bahan ajar yang digunakan diserahkan sepenuhnya kepada para pendidik sebagai tenaga profesional. Dalam hal ini, guru dituntut untuk mempunyai kemampuan mengembangkan bahan ajar sendiri. Untuk mendukung kurikulum, sebuah bahan ajar bisa saja menempati posisi sebagai bahan ajar pokok ataupun suplementer. Bahan ajar pokok adalah bahan ajar yang memenuhi tuntutan kurikulum. Sedangkan bahan ajar suplementer adalah bahan ajar yang dimaksudkan untuk memperkaya, menambah ataupun memperdalam isi kurikulum.

Apabila bahan ajar yang sesuai dengan tuntutan kurikulum tersebut tidak ada ataupun sulit diperoleh, maka membuat bahan belajar sendiri adalah suatu keputusan yang bijak. Untuk mengembangkan bahan ajar, referensi dapat diperoleh dari berbagai sumber baik itu berupa pengalaman ataupun pengetahauan sendiri, ataupun penggalian informasi dari narasumber baik orang ahli ataupun teman sejawat. Demikian pula referensi dapat kita peroleh dari buku-buku, media masa, internet, dll. Namun demikian, kalaupun bahan yang sesuai dengan kurikulum cukup melimpah bukan berarti kita tidak perlu mengembangkan bahan sendiri. Bagi siswa, seringkali bahan yang terlalu banyak membuat mereka bingung, untuk itu maka guru perlu membuat bahan ajar untuk menjadi pedoman bagi siswa. Telah banyak penelitian pengembangan (Research and Development) yang menghasilkan produk-produk bahan ajar yang berkualitas untuk pembelajaran. Beberapa penelitian pengembangan menghasilkan bahan ajar soal tipe PISA untuk tingkat SMP (Nizar et al., 2018; Noviarsyh Dasaprawira et al., 2019; Oktiningrum et al., 2016), , scientific bilingual worksheet untuk mahasiswa (Sagita et al., 2018), multimedia flipbook untuk SD kelas 6 (Andini et al., 2018), produk bahan ajar teks bacaan dengan konteks futsal untuk SMP (Effendi et al., 2019), soal open-ended untuk SMP (Kurniawan et al., 2018) dan masih banyak lagi. Keseluruhan penelitian hasil pengembangan tersebut menunjukkan bahwa produk bahan ajar yang dibuat bersifat praktis untuk digunakan dan berefek baik dalam pembelajaran.

Karakteristik sasaran menjadi pertimbangan lain dalam pembuatan bahan ajar. Bahan ajar yang dikembangkan orang lain seringkali tidak cocok untuk siswa kita. Ada sejumlah alasan ketidakcocokan, misalnya, lingkungan sosial, geografis, budaya, dll. Untuk itu, maka bahan ajar yang dikembangkan sendiri dapat disesuaikan dengan karakteristik sasaran. Selain lingkungan sosial, budaya, dan geografis, karakteristik sasaran juga mencakup tahapan perkembangan siswa, kemampuan awal yang telah dikuasai, minat, latar belakang keluarga dll. Untuk itu, maka bahan ajar yang dikembangkan sendiri dapat disesuaikan dengan karakteristik siswa sebagai sasaran.

Selanjutnya, pengembangan bahan ajar harus dapat menjawab atau memecahkan masalah ataupun kesulitan dalam belajar. Terdapat sejumlah materi pembelajaran yang seringkali siswa sulit untuk memahaminya ataupun guru sulit untuk menjelaskannya. Kesulitan tersebut dapat saja terjadi karena materi tersebut abstrak, rumit, asing, dsb. Untuk mengatasi kesulitan ini maka perlu dikembangkan bahan ajar yang tepat. Apabila materi pembelajaran yang akan disampaikan bersifat abstrak, maka bahan ajar harus mampu membantu siswa menggambarkan sesuatu yang abstrak tersebut, misalnya dengan penggunaan gambar, foto, bagan, skema, dll. Demikian pula materi yang rumit, harus dapat dijelaskan dengan cara yang sederhana, sesuai dengan tingkat berfikir siswa, sehingga menjadi lebih mudah dipahami (Depdiknas, 2008). 
Pentingnya e-Modul dapat dilihat dari hasil penelitian Komang (2017), yang memperoleh hasil: (1) hasil rancangan dan implementasi e-modul berbasis model pembelajaran project based learning pada mata pelajaran videografi untuk siswa kelas x desain komunikasi visual di SMK Negeri 1 Sukasada dinyatakan berhasil diterapkan berdasarkan beberapa uji yang dilakukan. (2) Hasil analisis data respon guru menunjukkan bahwa, didapatkan rata-rata skor respon sebesar 50, jika dikonversikan ke dalam tabel penggolongan respon maka termasuk pada kategori sangat positif. Sedangkan untuk respon siswa terhadap pengembangan e-modul didapatkan rata-rata skor respon sebesar 67,65, jika dikonversikan ke dalam tabel penggolongan respon siswa termasuk pada kategori sangat positif. Penelitian lain yang menunjukkan manfaat modul, oleh Abdullah (2012) yang menemukan bahwa "with the aid of the teaching module, the students gained hands-on experience in carrying out a team project and indirectly enhance their knowledge in space science"

Berdasarkan informasi yang diperoleh, mitra di SMAN 3 Takalar, tidak semua guru mampu membuat e-Modul dan mereka tidak memiliki banyak waktu untuk belajar sendiri pembuatan e-Modul. Padahal e-Modul sangat penting sebagai salah satu bahan ajar dengan penerapan teknologi. Berdasarkan pentingnya pembuatan bahan ajar seperti eModul dan agar penerapan teknologi tepat guna untuk membantu proses pembelajaran serta dengan melihat kebutuhan guru di SMAN 3 Takalar, maka kami melakukan Pelatihan Penyusunan Naskah dan Pembuatan e-Modul bagi Guru SMAN 3 Takalar.

\subsection{Permasalahan Mitra}

SMAN 3 Takalar merupakan salah satu unit penyelenggaraan pendidikan untuk sekolah menengah atas yang terletak di kabupaten Takalar. Pada SMAN 3 Takalar, terdapat lebih banyak guru yang berusia di atas 40 tahun. Mereka adalah guru-guru senior yang sudah professional dalam pembuatan bahan ajar. Mereka sudah menguasai teknik tentang bagaimana meramu bahan ajar agar siswa lebih paham dan mudah mengerti. Kesulitan guru-guru di usia tersebut adalah pada penggunaan teknologi dalam pembelajaran dan transfer pengetahuan.

Pembaharuan kurikulum pendidikan bertujuan agar konten kurikulum sesuai dengan perkembangan peserta didik. Namun pembaruan ini menyebabkan guru harus mengubah kembali bahan ajar yang sudah diramu dengan baik dan jika bahan ajar berubah padahal guru-guru sudah mencetak secara besar-besaran, maka biaya pembuatan bahan ajar akan semakin besar. Belum lagi jika bahan ajar tersebut memuat gambar yang berwarna-warni, biaya percetakannya sangat mahal. Untuk mengantisipasi dan untuk mengatasi masalah pembiayaan yang mahal ini maka perlu adanya inovasi atau teknologi yang dapat menjadi solusinya. Salah satu solusi dari permasalahan tersebut adalah dengan pembuatan e-Modul.

Pembuatan e-Modul memerlukan pengetahuan, keahlian dan keterampilan khusus yang berhubungan dengan penggunaan teknologi dan kemampuan pedagogik. Untuk belajar sendiri, dibutuhkan waktu yang lama dan kesungguhan. Menurut data, hanya sebagian kecil dari guru-guru di SMAN Takalar yang menguasai teknologi komputer. Mereka masih membutuhkan pelatihan-pelatihan untuk mengasah kemampuan mereka dalam penggunaan teknoogi, terkhusus dalam pembuatan e-Modul.

\subsection{Perumusan Masalah Mitra}

Sesuai dengan hasil diskusi dan kesepakatan antara tim pengusul dengan mitra, permasalahan mitra yang menjadi prioritas dan perlu untuk diselesaikan melalui program PKM ini, sebagai berikut:

1. Mahalnya biaya percetakan Modul,

2. Kurangnya pengetahuan guru dalam menyusun naskah e-Modul,

3. Kurangnya keterampilan guru dalam membuat e-Modul. 


\section{Target Luaran dan Metode}

\subsection{Solusi dan Target Luaran}

Berdasarkan permasalahan yang dihadapi mitra, solusi yang ditawarkan, sebagai berikut:

1. Pemberdayaan teknologi di sekolah mitra melalui pembuatan dan penggunaan e-Modul yang dapat meminimalisir biaya untuk pendidikan karena tidak perlu ada biaya percetakan modul,

2. Pembinaan keterampilan pengelolaan pembelajaran berbasis teknologi dengan teknologi berupa e-Modul,

3. Pembinaan keterampilan penyusunan naskah dan pembuatan e-Modul bagi guru-guru di sekolah mitra.

Adapun luaran yang hendak diupayakan dan dicapai melalui kegiatan PKM ini adalah peningkatan pengetahuan dan keterampilan profesional para guru di sekolah mitra agar semakin meningkatkan kualitas dan hasil pembelajaran melalui:

1. Peningkatan pengetahuan guru di sekolah mitra dalam mengoptimalkan pembelajaran dengan bantuan teknologi berupa e-Modul (peningkatan pemahaman dan keterampilan masyarakat),

2. Peningkatan keterampilan guru di sekolah mitra dalam membuat bahan ajar e-Modul (peningkatan pemahaman dan keterampilan masyarakat),

3. Terciptanya produk berupa e-Modul untuk beberapa mata pelajaran.

4. Peningkatan kualitas produk bahan ajar dari slide persentase materi dan modul hasil cetakan yang membutuhkan biaya besar menjadi e-Modul.

\subsection{Metode Pelaksanaan}

Langkah-langkah yang ditempuh guna melaksanakan solusi atas permasalahan yang dihadapi oleh sekolah mitra, yaitu dengan memberikan pelatihan dan pendampingan:

1. Penjelasan pentingnya pemanfaatan teknologi dalam pembelajaran.

Metode pendekatan yang dipakai pada kegiatan ini adalah materi dipresentasikan secara pleno, dengan menampilkan pentingnya teknologi dalam pembelajaran, mengenalkan contoh-contoh teknologi yang dapat digunakan dalam proses pembelajaran, dan menumbuhkan motivasi guru untuk lebih memanfaatkan teknologi demi meningkatkan minat dan hasil belajar siswa.

2. Pelatihan pengelolaan pembelajaran berbasis teknologi.

Diarahkan untuk menumbuhkan pengetahuan dan pemahaman cara-cara pengelolaan pembelajaran berbasis teknologi (e-Modul), dan cara-cara mengoptimalkan pembelajaran berbasis teknologi. Metode pendekatan dengan mempresentasikan materi kemudian menampilkan contoh situasi yang perlu diatasi guru saat pembelajaran berbasis teknologi dan solusi menghadapinya.

3. Pelatihan penyusunan naskah dan pembuatan e-Modul.

Guru-guru SMAN 3 Makassar atau peserta pelatihan diberikan contoh e-Modul. Contoh ditampilkan dengan LCD, secara pleno ke seluruh peserta pelatihan. Ditampilkan bagaimana navigasi-navigasi dalam e-Modul. Diperlihatkan aplikasi yang digunakan dalam pembuatan e-Modul. Kemudian peserta pelatihan memulai menyusun naskah sebagai bahan e-Modul. Naskah diamati dan pemateri mencoba memahami alur e-Modul yang dirancang oleh peserta pelatihan atau guru-guru. Setelah naskah bagus dan sesuai dengan tujuan pembuatan e-Modul maka mulailah pembuatan e-Modul. Peserta dibimbing langkah demi langkah dalam pembuatan e-Modul dan bagi yang mengalami kesulitan maka dibantu satu per satu.

4. Pendampingan kepada para peserta pelatihan dalam rangka merancang, membuat, dan mengembangkan multimedia pembelajaran interaktif. 
Peserta pelatihan adalah guru-guru di SMAN 3 Takalar yang berpartisipasi sebagai peserta pelatihan dan menjadi perancang dan pembuat e-Modul sesuai dengan mata pelajaran yang diampu. Keberhasilan kegiatan ini dapat dilihat dari kemampuan guru menyusun naskah dan membuat e-Modul dan hasil karya guru berupa e-Modul untuk beberapa mata pelajaran.

\section{Hasil dan Pembahasan}

Kegiatan Pelatihan Penyusunan Naskah dan Pembuatan E-Modul bagi Guru-guru di SMAN 3 Takalar berjalan lancar dan sesuai rencana. Guru-guru di SMAN 3 Takalar dari berbagai bidang studi menjadi peserta pelatihan yang merancang naskah dan membuat e-Modul sesuai dengan mata pelajaran yang diampu Kegiatan berlangsung pada hari Selasa, 7 Januari 2020, mulai pukul 08.00 sampai pukul 16.00 WITA untuk sesi tatap muka, dan berlanjut untuk penyelesaian tugas penyusunan naskah dan pembuatan e-modul. Pada penyusunan naskah dan pembuatan e-modul, peserta diberikan waktu penyelesaian selama satu minggu.

Pelatihan dan pendampingan peserta untuk sesi tatap muka mengikuti langkah-langkah berikut:

a. Penjelasan pentingnya pemanfaatan teknologi dalam pembelajaran.

Presentasi materi oleh narasumber, dengan menampilkan pentingnya teknologi dalam pembelajaran, mengenalkan contoh-contoh teknologi yang dapat digunakan dalam proses pembelajaran, baik itu teknologi yang dapat digunakan di dalam kelas seperti komputer, laptop, LCD, smartphone dan lain-lain, maupun teknologi pembelajaran online seperti e-learning, google classroom, e-book dan e-modul. Narasumber juga memberikan materi dan semangat yang dapat menumbuhkan motivasi guru untuk lebih memanfaatkan teknologi demi meningkatkan minat dan hasil belajar siswa. Dalam tahapan pendampingan ini, ditanamkan pula self-concept guru agar mereka mampu menanamkan selfconcept dalam diri siswa, sebab self-concept berpengaruh posiitif dan signifikan terhadap hasil belajar (Suciati, et al., 2020). Terdapat beberapa guru yang terkendala dalam penggunaan teknologi karena kurangnya pengetahuan dan keterampilannya dalam menggunakan komputer, aplikasi-aplikasi dalam komputer maupun aplikasi smartphone serta kurangnya keterampilan penggunaan internet. Dari 16 peserta, terdapat 12 orang yang sudah memiliki kemampuan dasar dalam menggunakan perangkat komputer dan internet, dan masih ada 4 orang yang belum memiliki kemampuan dasar penggunaan komputer dan internet. Mereka yang tidak kurang menguasai cara pengetikan dan insert beberapa simbol serta terlihat masih kaku dalam menggunakan komputer. Mereka juga terlihat bingung saat kami meminta untuk membuka browser di smartphone.

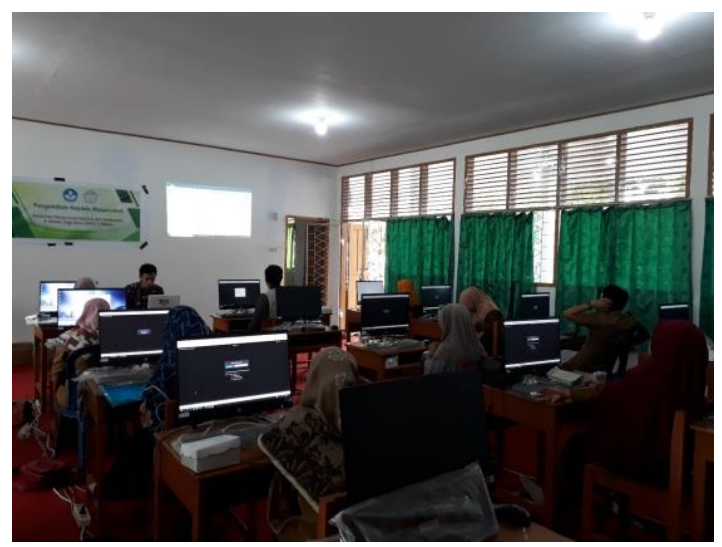

Fig. 1. Penjelasan pentingnya pemanfaatan teknologi dalam pembelajaran

b. Pelatihan pengelolaan pembelajaran berbasis teknologi.

Narasumber mempraktekkan sekilas mengenai pembelajaran menggunakan e-Modul, dan cara-cara mengoptimalkan pembelajaran menggunakan e-Modul. Dalam praktek pembelajaran dengan e-Modul, peserta dapat menikmati 
mudahnya akses e-Modul dan mudahnya belajar dengan e-Modul. Navigasi daftar isi e-Modul juga memudahkan dalam memilih sub bab materi yang diinginkan dipelajari.

c. Pelatihan penyusunan naskah dan pembuatan e-Modul.

Guru-guru SMAN 3 Takalar atau peserta pelatihan diberikan contoh e-Modul. Contoh ditampilkan dengan LCD, secara pleno ke seluruh peserta pelatihan. Ditampilkan navigasi-navigasi dalam e-Modul.

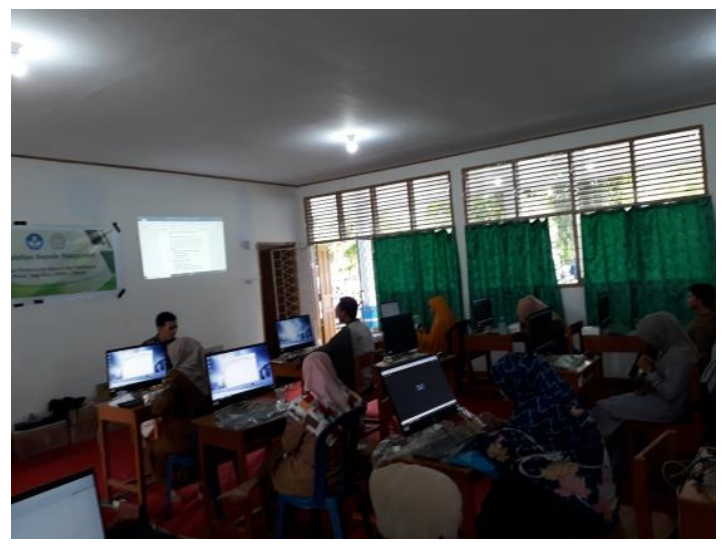

Fig. 2. Proses Pelatihan oleh Narasumber

\section{d. Penyusunan Naskah e-Modul}

Setelah menunjukkan tampilan e-Modul yang dimiliki oleh narasumber, peserta dibimbing untuk menyusun naskah sebagai persiapan dalam pembuatan e-Modul. Pada sesi ini, narasumber mengkorfimasi bidang studi yang diampu oleh para guru peserta pelatihan. Ada yang mengajarkan bidang studi Matematika, Bahasa Indonesia, dll . Perbedaan bidang studi pengajaran tidak menjadi persoalan dalam pembuatan e-Modul karena e-Modul bisa dibuat oleh bidang studi apa saja. Hanya saja, susunan naskahnya yang akan berbeda karena ada beberapa bidang studi yang membutuhkan naskah yang berisi gambar-gambar, simbol, dan tabel yang membutuhkan perlakuan khusus agar tampilan naskah dalam e-Modulnya tetap sesuai harapan dan sesuai tujuan e-Modul serta dapat memenuhi kompetensi dasar peserta didik. Dari beberapa pemaparan materi mengenai penyusunan naskah untuk pembuatan e-Modul, langkah-langkah penting penyusunan naskah yaitu: pembuatan isi atau bahan e-Modul dibuat dan disusun dalam bentuk file Microsoft Office Word; tidak boleh ada header dan footer ataupun nomor halaman dalam file tersebut; untuk bidang studi matematika, fisika, kimia atau bidang studi yang membutuhkan simbol-simbol dan tabel, semua rumus dan tabel diubah dalam bentuk gambar terlebih dahulu, pengubahan tersebut boleh dengan cara screenshot kemudian menyesuaikan dengan lokasi rumus atau tabel lalu hapus rumus atau tabel yang telah ada sebelumnya. Agar memudahkan screenshot, boleh dengan menggunakan snipping tool yang merupakan tool bawaan dari windows, semua computer memiliki aplikasi ini dan cara penggunaannya sangat mudah menyesuaikan dengan apa yang dibuthkan; tiap halaman atau page harus dirapikan; penebalan huruf (Bold), huruf Italic, dan penggunaan huruf kapital bentuknya akan tetap sesuai format dalam Microsoft Office Word, tidak mengalami perubahan; jika sudah diperbaiki semua susunan naskah yang dibuat untuk e-Modul, save terlebih dahulu, kemudian pilih save as, cari tempat penyimpanan yang diinginkan, saat akan save dan memilih nama file, ganti tipe dengan Web Page Filtered, klik yes, kemudian cari dan pastikan foldernya apakah sudah dalam bentuk format html.

Selama penyusunan naskah untuk e-Modul, narasumber menyampaikan materi sambil memeriksa satu persatu apa yang dilakukan oleh peserta didik. Narasumber dan tim pengabdi lainnya berkeliling melihat dan membimbing praktek penyusunan naskah yang dilakukan oleh guru-guru peserta pelatihan. Dalam pembuatan naskah dan pembmbingan peserta pelatihan, pemeriksaan simbol-simbol matematika membutuhkan waktu lebih lama karena pembimbing dan peserta pelatihan harus mengecek satu per satu dan pada bidang studi matematika ada banyak sekali penggunaan simbol dan rumus matematika apalagi rumus matematika ini untuk siswa SMA. 


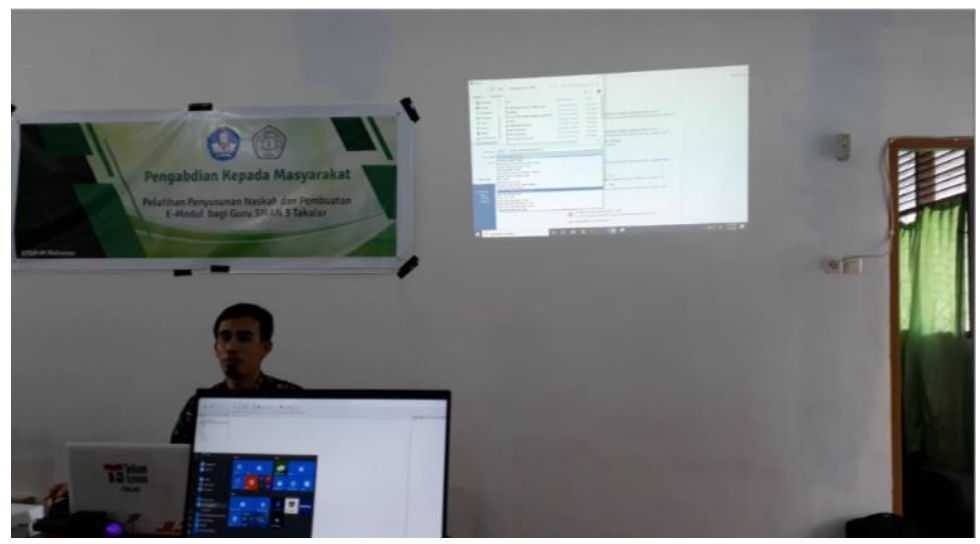

Fig. 3. Penyusunan Naskah e-Modul dan Penjelasan Cara Penyimpanan

\section{e. Pembuatan e-Modul}

Proses penyusunan naskah untuk pembuatan e-Modul telah dilakukan Bersama-sama dengan peserta pelatihan penyusunan naskah dan pembuatan e-Modul. Beberapa naskah peserta sudah siap namun ada 3 orang yang menyusul untuk menyempurnakan naskahnya. Terdapat juga beberapa peserta yang memang sudah memiliki naskah awal untuk modul, hanya mengalami beberapa perbaikan, menyesuaikan dengan naskah untuk e-Modul karena beberapa formatnya ada yang berbeda dan perlu perbaikan.

Pembuatan e-Modul menggunakan bantuan aplikasi sigil. Aplikasi ini sangat mudah penginstallannya dan narasumber juga menjelaskan dengan baik cara penginstallannya, langkah demi langkah, dan disediakan pula konten youtube yang bias memudahkan peserta mengakses materi jika saja dalam proses penginstalllan mandiri nanti, ada yang mengalami kesulitan. Beberapa hal-hal penting yang harus diperhatikan dalam pembuatan e-Modul dengan aplikasi sigil, yaitu jangan lupa menyiapkan naskah untuk e-Modul, buka aplikasi sigil, kemudian buka naskah yang sudah disiapkan lewat aplikasi sigil, perhatikan bahwa untuk melihat naskah yang sudah disiapkan untuk e-Modul, pada pembacaan filenya, secara default itu akan menunjukkan EPUB files*, ganti dengan HTML, sehingga muncullah naskah e-Modul yang sudah disiapkan, jangan lupa sesuaikan atau cari terlebih dahulu dimana menyimpan file naskah e-Modul tersebut. Format dan bentuk tulisan yang akan tampil dalam aplikasi sigil sama dengan tampilan dalam Microsoft office Word yang dibuat sebelumnya, baik besar hurufnya, format bold dan italicnya. Hal lain yang perlu diperhatikan dalam pembuatan e-Modul yaitu merapikan tampilan isi e-Modul dengan memeriksa tiap tampilan naskah, memperbaiki spasi dan susunan kata. Jika pembuat e-Modul ingin agar tampilan e-Modulnya seperti buku maka berarti pembuat e-Modul atau peserta pelatihan harus memformat e-Modul seperti tampilan buku, minimal harus memiliki sampul dan daftar isi. Pembuatan sampul e-Modul dengan memilih tools cover pada aplikasi sigil, sampul dipilih dari gambar yang sudah disiapkan. Gunakan metadata untuk menambah properties pada e-Modul. Properties dapat berupa judul, author, Bahasa, ISBN. Cara menambahkan ciri-ciri untuk metadata yaitu dengan add Basic. Dalam pembuatan e-Modul dengan aplikasi sigil, pembuat atau peserta pelatihan dapat menambahkan daftar isi. Bab, sub bab, dan sub-sub bab dapat dipisah-pisahkan dan terbentuk otomatis hanya dengan mengklik tools tertentu dalam aplikasi sigil. Gunakan Heading pada aplikasi sigil, h1 untuk pilihan Bab-bab dalam naskah e-Modul, klik h2 untuk sub bab dan seterusnya. Pembuat e-Modul atau peserta pelatihan hanya tinggal menyesuaikan dengan mengklik bab dan sub bab kemudian mengklik pilihan headingnya. Daftar isi terbentuk otomatis setelah semua disesuaikan.

Dalam proses pembuatan e-Modul peserta mengalami kendala pada saat pembacaan file untuk memilih naskah yang akan dikonvert menjadi e-Modul dengan aplikasi sigil karena aplikasi pengetikan naskah yang ada dalam komputer laboratorium yang digunakan saat itu bukan aplikasi Microsoft Office Word, sehingga sulit terbaca oleh aplikasi sigil. Hanya ada beberapa computer yang bisa yaitu sebanyak 5 komputer dan laptop, sehingga peserta memformat sendiri diri mereka ke dalam bentuk kelompok-kelompok yang terdiri dari 5 kelompok agar mereka tetap dapat mengikuti jalannya materi pembuatan e-Modul. 


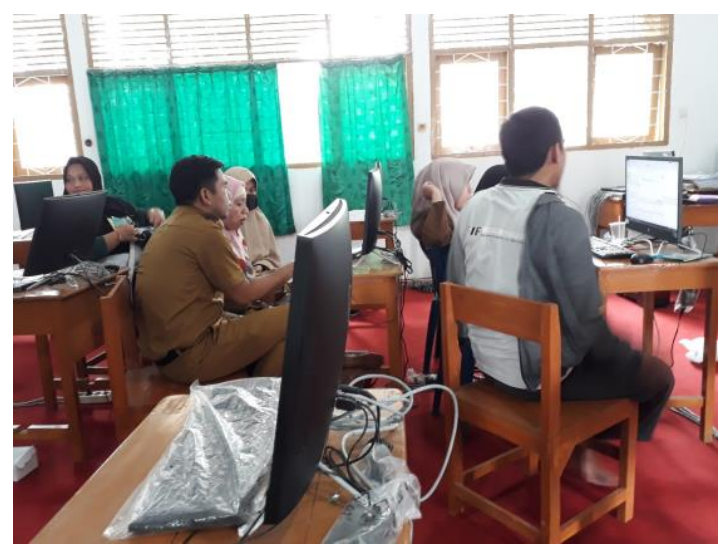

Fig. 4. Pembentukan Kelompok Peserta Pelatihan

Pada saat kegiatan tatap muka pelatihan penyusunan naskah dan pembuatan e-Modul, seluruh peserta terlihat antusias dan bersemangat. Ada yang berkomentar bahwa materi inilah yang penting dan dibutuhkan di zaman sekarang, melihat perkembangan teknologi, jangan sampai guru ketinggalan informasi dan kurang kemampuan dan keterampilan untuk mengikuti perkembangan zaman. Antusias dan semangat peserta terlihat dari keseriusan mereka mengikuti langkah demi langkah pembuatan e-Modul, mulai dari penyusunan naskah sampai pada pembuatan eModul hingga tercipta e-Modul buatan mereka.

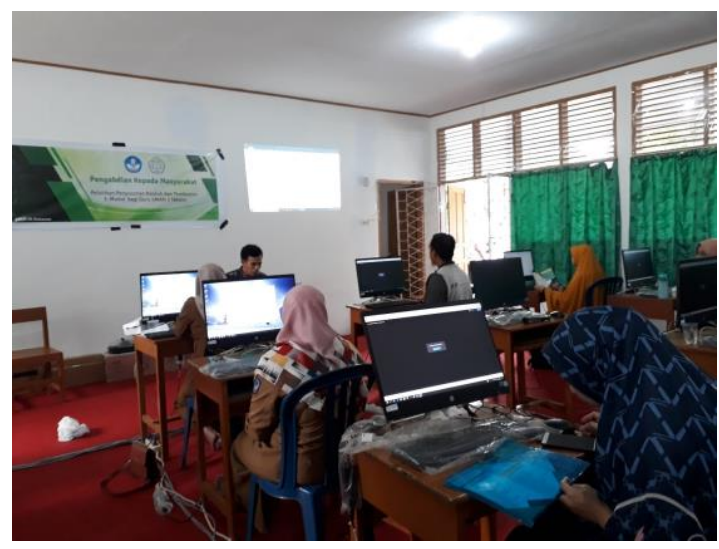

Fig. 5. Antusiasme Peserta Pelatihan

Proses pelatihan tatap muka hanya berlangsung sehari dan kemudian dilanjutkan dengan penyelesaian tugas pembuatan e-Modul yang lebih baik dan lebih kreatif oleh masing-masing peserta pelatihan penyusunan naskah dan pembuatan e-Modul. Penyelesaian tugas pembuatan e-Modul tersebut tetap didampingi oleh narasumber dan tim pengabdi. Setiap pertanyaan dan kesulitan siswa dibimbing dengan baik sampai peserta bisa menyelesaikan sendiri eModulnya.

f. Pendampingan kepada para peserta pelatihan dalam rangka merancang, membuat, dan mengembangkan eModul. 


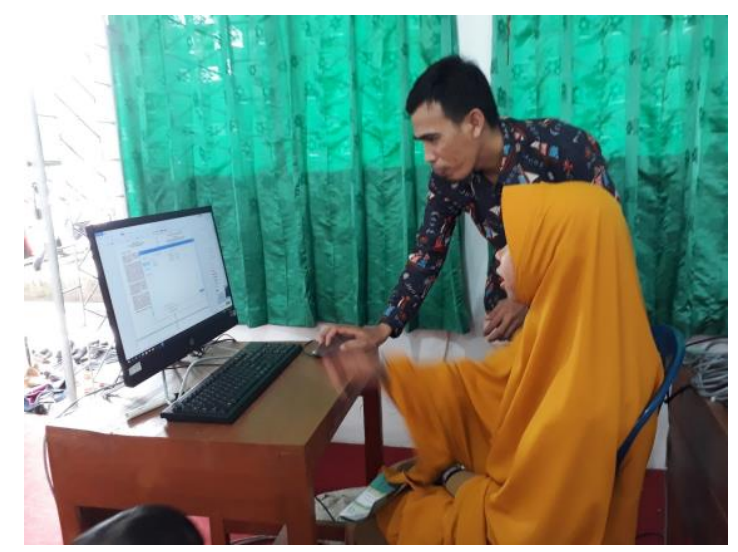

Fig. 6. Pendampingan Peserta Pelatihan oleh Narasumber

Pendampingan peserta pelatihan penyusunan naskah dan pembuatan e-Modul dilakukan sepanjang pelatihan tatap muka hingga penyelesaian tugas pembuatan e-Modul. Pendampingan dilakukan oleh narasumber secara langsung, dibantu oleh tim pengabdi. Karena pada saat pelatihan memasuki bagian pembuatan e-Modul, terjadi kendala yaitu tidak semua computer mampu membuka file naskah e-Modul yang sudah disusun, dan ada beberapa computer yang bisa, maka terbentuk 5 kelompok. Pendampingan dilakukan dengan memantau dan membantu kegiatan setiap kelompok. Proses pembuatan e-Modul dengan setting kelompok terlihat lebih ramai dan agak rebut, namun keributan itu karena keseruan mereka membuat e-Modul, dan situasi tetap terkontrol karena tim pengabdi tetap mendampingi dan mengawasi seluruh kelompok. Selain pendampingan oleh narasumber dan tim pengabdi, proses pelatihan juga terbantu oleh adanya beberapa peserta yang saling membantu dalam pembuatan e-Modul. Mereka ada yang berkeliling membantu sesama peserta pelatihan saat teman mereka memanggil. Dalam pendampingan ini diberikan target pembuatan e-Modul. Penetapan target memberikan pelatihan proyek pembelajaran bagi guru, yang disebut dengan model Project Based Learning. Pelaksanaan pembelajaran dengan Project Based Learning (PjBL) mampu mengasah kemampuan berpikir kritis (Sutamrin \& Khadijah, 2021). Diharapkan guru-guru dapat memenuhi target minimal 1 proyek pembuatan e-Modul Pembelajaran.

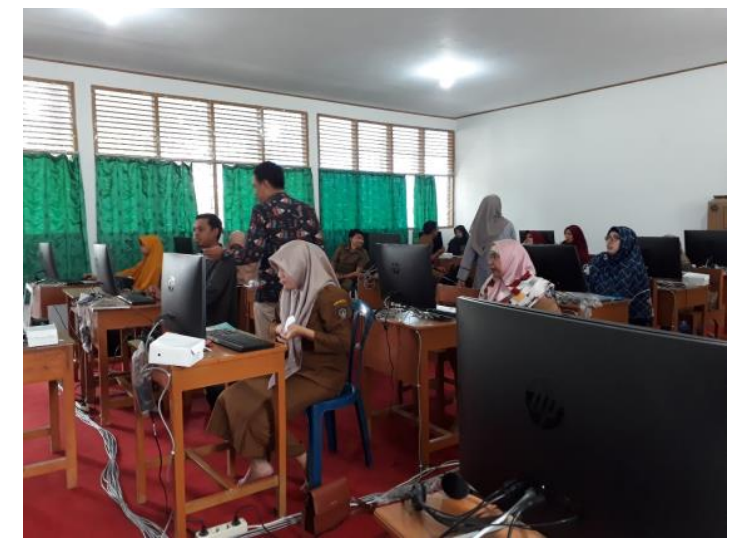

Fig. 7. Pendampingan Peserta Pelatihan oleh Narasumber dan Tim Pengabdi

Keberhasilan pelatihan penyusunan naskah dan pembuatan e-Modul dapat dilihat dari kemampuan guru menyusun naskah dan membuat e-Modul serta hasil karya guru berupa e-Modul untuk beberapa mata pelajaran. Indikator keberhasilan pelatihan ini tampak dari evaluasi dalam pelatihan. Evaluasi pelatihan penyusunan naskah dan pembuatan e-Modul dilakukan dengan melihat aktivitas peserta pelatihan selama proses tatap muka dan dengan menilai e-Modul yang telah dibuat oleh masing-masing peserta pelatihan. 
Selama proses tatap muka, terlihat kemampuan guru atau peserta pelatihan dalam menyusun naskah e-Modul. Terdapat 13 orang dari 16 peserta mampu menyusun naskah untuk persiapan pembuatan e-Modul atau $81 \%$ peserta mampu menyusun naskah e-Modul walaupun tidak semua naskah sudah sempurna, mengingat keterbatasan waktu dan sumber referensi yang mereka bawa dan siapkan sehingga masih memerlukan banyak perbaikan dan kelengkapan untuk naskah e-Modulnya. Penyempurnaan susunan naskah dilakukan pada saat tugas penyelesaian karya e-Modul.

Kemampuan pembuatan e-Modul terlihat selama proses tatap muka dan juga terlihat dari hasil karya e-Modul yang dibuat oleh peserta. Penilaian autentik kemampuan pembuatan e-Modul lebih terlihat saat proses tatap muka karena terlihat bahwa benar-benar peserta yang melakukan pembuatan e-Modul tersebut, langkah demi langkah. Selama proses tatap muka, terlihat bahwa sebanyak 14 orang mampu mempublish e-Modulnya dari aplikasi sigil, atau terdapat $87 \%$ mampu membuat e-Modul. Naskah yang dikonvert menjadi e-Modul hanya beberapa naskah karena kendala keterbatasan komputer yang mampu menunjang aplikasinya dan pembentukan kelompok-kelompok saat pembuatan e-Modul, hanya bebrapa peserta yang mengkonvert betul susunan naskahnya karena hanya ada satu flashdisk yang dapat digunakan. Hal ini berdampak pada semakin banyaknya yang terlihat mampu membuat e-Modul walaupun naskahnya belum siap, tapi mereka mampu mengikuti langkah pembuatan e-Modul.

\section{Kesimpulan}

Pelaksanaan pelatihan penyusunan naskah dan pembuatan e-Modul mewujudkan: (1) peningkatan pengetahuan guru di sekolah mitra dalam mengoptimalkan pembelajaran dengan bantuan teknologi berupa e-Modul (peningkatan pemahaman dan keterampilan masyarakat), (2) peningkatan keterampilan guru di sekolah mitra dalam membuat bahan ajar e-Modul (peningkatan pemahaman dan keterampilan masyarakat), (3) terciptanya produk bahan ajar berupa e-Modul untuk beberapa mata pelajaran, (4) peningkatan kualitas produk bahan ajar dari slide persentase materi dan modul hasil cetakan yang membutuhkan biaya besar menjadi e-Modul.

\section{References}

Abdullah, Mardina dkk. (2012). Development of UKM-SID teaching module for space science Education. 6th International Forum on Engineering Education 2012. Prooceding.

Andini, S., Budiyono, \& Fitriana, L. (2018). Developing flipbook multimedia: The achievement of informal deductive thinking level. In Journal on Mathematics Education (Vol. 9, Issue 2, pp. 227-238). https://doi.org/10.22342/jme.9.2.5396.227-238

Effendi, K. N. S., Zulkardi, Putri, R. I. I., \& Yaniawati, P. (2019). Developing mathematics worksheet using futsal context for school literacy movement. In Journal on Mathematics Education (Vol. 10, Issue 2, pp. 203-214). https://doi.org/10.22342/jme.10.2.7307.203-214

Khadijah, K., \& Khaerati, K. (2018). Pengaruh Pelatihan terhadap Peningkatan Kemampuan Membuat Multimedia Pembelajaran Interaktif bagi Guru-Guru SMP. Jurnal Kompetensi, 11(2), 96-99.

Komang, I Priatna dkk. (2017). Pengembangan E-Modul Berbasis Model Pembelajaran Project Based Learning Pada Mata Pelajaran Videografi untuk Siswa Kelas X Desain Komunikasi Visual di SMK Negeri 1 Sukasada. Jurnal Nasional Pendidikan Teknik Informatika (JANAPATI). Volume 6, Nomor 1, 70-78.

Kucirkova, N., Evertsen-Stanghelle, C., Studsrød, I., Jensen, I. B., \& Størksen, I. (2020). Lessons for child-computer interaction studies following the research challenges during the Covid-19 pandemic. International Journal of Child-Computer Interaction, 26, 100203. https://doi.org/10.1016/j.ijcci.2020.100203

Kurniawan, H., Putri, R. I. I., \& Hartono, Y. (2018). Developing open-ended questions for surface area and volume of beam. In Journal on Mathematics Education (Vol. 9, Issue 1, pp. 157-168). https://doi.org/10.22342/jme.9.1.4640.157-168

Muthuprasad, T., Aiswarya, S., Aditya, K. S., \& Jha, G. K. (2021). Students' perception and preference for online education in India during COVID -19 pandemic. Social Sciences \& Humanities Open, 3(1), 100101. https://doi.org/10.1016/j.ssaho.2020.100101 
Naim, Ngainun. (2011). Menjadi Guru Inspiratif (Memberdayakan dan Mengubah Jalan Hidup Siswa. Yogyakarta: Pustaka.

Nizar, H., Putri, R. I. I., \& Zulkardi. (2018). Developing pisa-like mathematics problem using the 2018 Asian Games football and table tennis context. In Journal on Mathematics Education (Vol. 9, Issue 2, pp. 183-194). https://doi.org/10.22342/jme.9.2.5246.183-194

Noviarsyh Dasaprawira, M., Zulkardi, \& Susanti, E. (2019). Developing mathematics questions of Pisa type using Bangka context. In Journal on Mathematics Education (Vol. 10, Issue 2, pp. 303-314). https://doi.org/10.22342/jme.10.2.5366.303-314

Oktiningrum, W., Zulkardi, \& Hartono, Y. (2016). Developing PISA-like mathematics task with Indonesia natural and cultural heritage as context to assess students' mathematical literacy. In Journal on Mathematics Education (Vol. 7, Issue 1, pp. 1-8). https://doi.org/10.22342/jme.7.1.2812.1-8

Restiani, Rusi, dkk. (2014). Profil Pemanfaatan Teknologi Informasi dan Komunikasi (TIK) sebagai Media dan Sumber Pembelajaran oleh Guru Biologi. Edusains, 6(01), 50-66.

Rusman. (2013). Belajar dan Pembelajaran Berbasis Komputer. Bandung: Alfabeta.

Sagita, L., Widagsa, R., \& Dwipa, N. M. S. (2018). Developing Bilingual Scientific-Worksheet for Indefinite Integral. Journal on Mathematics Education, 9(2), 249-258.

Suciati, Indah, Khadijah, Khaerani, Abdul Manaf. (2020). Self-Concept \& Mathematics Achievement: A Metaanalysis. Universal Journal of Educational Research. 8(12A): 7676-7681, 2020. https://doi.org/10.13189/ujer.2020.082554.

Sujoko. (2013). Pemanfaatan Teknologi Informasi dan Komunikasi sebagai Media Pembelajaran di SMP Negeri 1 Geger Madiun. Jurnal Kebijakan dan Pengembangan Pendidikan, 1(1), 71-77.

Sutamrin, S., \& Khadijah, K. (2021). Analisis Kemampuan Berpikir Kritis dalam Project Based Learning Aljabar Elementer. EQUALS: Jurnal Ilmiah Pendidikan Matematika, 4(1), 28-41. https://doi.org/10.46918/equals.v4i1.892 